\title{
Globalisation and Security in the Taiwan Straits
}

\author{
UWE WUNDERLICH*
}

(University of East Anglia)

Only recently the Sino-Taiwanese issue has again been in the headlines of the international media. On Saturday, 3 August 2002, Taiwan’s President Chen Shui-bian insisted in a passionate speech that there is 'one country on each side' of the Taiwan Strait. He went even further by calling for new legislation that would allow a referendum to be held on changing the island's current international status, saying that this would be a 'basic human right' (J. Gittings, 'Independence Call by Taiwan Risks war, Warns China', The Guardian [6 August 2002]). Chen's remarks resulted in a furious response from the mainland. Although the conflict between Beijing and Taipei can be interpreted as a legacy of the Chinese Civil War, the tensions gained in intensity during the 1990s. The following article suggests that the linkages and dynamics between the globalisation process and international security are increasingly important for a better understanding of the development of relations at the international level in general and in the China-Taiwan conflict in particular.

Globalisation and international security have been prominent topics in the academic literature on international relations in the post-Cold-War world. However, until recently the linkages between the two concepts have been under-researched. But it is precisely this connection which is crucial for a better understanding of the developments and dynamics of conflicts at the international level. The globalisation process has a variety of effects on the domestic and foreign realities that national governments face and therefore influences the security environment of inter-state relations.

The purpose of this article is twofold. First, it aims to contribute to the general discussion surrounding the concept of globalisation and its consequences for international security and inter-state relations. And, secondly, it attempts to offer a deeper insight into the complexities of security relations across the Taiwan Strait by connecting them to the globalisation process. In order to achieve these goals the discussion is divided into two categories. The first section establishes definitional clarity of the notion of globalisation and its implications for national governance and, consequently, national and international security. The second section argues that the globalisation process is having a decisive impact on the development of the conflict between the People's Republic of China (PRC) and the Republic of China on Taiwan (ROC). Depending on the definition of globalisation it is possible to claim that forces associated with the globalisation process have become increasingly significant factors of international relations in the post-Cold-War world. * Uwe Wunderlich, School of Economic and Social Studies, University of East Anglia, Norwich NR4 7TJ, UK. Fax:_44-1603-250434 Email: J.Wunderlich@uea.ac.uk

An earlier version of this article was presented at the 2002 North American Taiwan Studies Association (NATSA) Conference at the University of Chicago.

For their help and constructive comments I wish to thank Stephanie Lawson, Pat Chilton, Vassiliki Koutrakou, Nieves Pe'rez-Solo'rzano Borraga'n, Andy Patmore, Mike Bowker, Rwei-Ren Wu, Chih-Mei Luo and two anonymous referees.

ISSN 1478-1158 print/ISSN 1478-1166 online/03/020000-00 Øつ 2003 Taylor \& Francis Ltd DOI: $10.1080 / 1478115032000079822$

122 Uwe Wunderlich

Moreover, in this period the Sino-Taiwanese conflict has gained in intensity and magnitude. This leads to the assumption of an association between the globalisation process and the development of international security across the Taiwan Strait. The article scrutinises the effects of globalisation on the domestic situations in the PRC and Taiwan. Of particular interest in that context is the formation of a Taiwanese identity. Therefore, it is important to mention the constructivist tradition which has been largely responsible for bringing identity issues to light in international relations theory—something that neither liberalism nor realism has done before in a satisfactory manner. The article concludes by outlining the impact of globalisation on PRC-ROC relations. The linkage between the domestic and the 
international level is illustrated by two scenarios utilising the analytical instruments offered by the neorealist and neoliberal schools of thought in order to demonstrate the impact of globalisation on international security across the spectrum of theoretical debate. The scenarios serve demonstrative purposes only. The article does not aim to enter the long-lasting debate between proponents of neoliberalism and neorealism.

\section{Globalisation, National Governance and International Security}

The current international environment is characterised by a multitude of forces. Among them those which can be attributed to the globalisation process and its consequences are of crucial importance for the development, politics and analysis of inter-state relations. However, the term 'globalisation' has been used so often in academic circles, political rhetoric and the daily press that it has become a hollow catchphrase. Therefore, the first part of the paper attempts to establish definitional clarity of the concept and its effects on national governance and international security. However, an extensive discussion is deliberately avoided, since this topic covers fairly familiar ground for every student of international relations.

The academic literature offers an amazing variety of different approaches and theories concerning the notion of globalisation. Almost every researcher in the social sciences seems to have something to add to the ongoing discourse. Jan Art Scholte presents the dilemma by offering a brief collection of definitions.1 They represent a number of contrasting views ranging from defining globalisation as the development of a global society, emphasising the rising internationalisation of production and capital, or the international division of labour, to a focus on issues such as transnational migration or external environment effects. Some critics regard globalisation as a misconception altogether. In their eyes, globalisation is something of a myth, created by neoliberals in order to foster the spread of capitalism and to obscure the suppression of local cultures and the 'Americanisation' of the international political economy.2 This highlights the contradictions and confusions surrounding the concept. Globalisation, it seems, means different things to different people. This makes it even more necessary to clarify the terminology when dealing with such a notion. Perhaps one of the most constructive definitions has been offered by David Held. According to him and other scholars, globalisation can be interpreted as a multidimensional and multifaceted process that is changing the very nature of political, social and economic relations.3 It is a term describing 1 J. A. Scholte, 'The Globalization of World Politics', in J. Baylis and S. Smith (eds), The Globalization of World Politics-An Introduction to International Relations (Oxford: Oxford University Press, 1997), p. 15.

2 The sceptical thesis makes a contrast between globalisation and the intensification of international trade. See P. Hirst, G. Thompson, Globalisation in Question: The

International Economy and Possibilities of Governance, 2nd edn (Cambridge: Polity Press, 1999); P. Hirst, 'The Global Economy: Myths and Realities', International Affairs, 73 (1997); D. Held, A. McGrew, D. Goldblatt and J. Perraton, Global Transformations-Politics, Economics and Culture (Cambridge: Polity Press, 1999), p. 5.

3 See J. Krause, 'Overview', in Council for Asia-Europe Cooperation, Strengthening International Order-The Role of Asia-Europe Co-operation (Tokyo: Japan Center for International Exchange, 2000), p. 10. See also D. Held, 'Democracy and Globalization', MPIfG Working Paper $97 / 5$ (1997), p. 2, http://www.mpi-fg-koeln.mpg.de/ pu/workpap/wp97-5/wp97-5.html. Accessed 19 September 2001.

Globalisation and Security in the Taiwan Straits 123

certain trends, factors and forces that share a transnational nature and penetrate all levels of international relations. This is a rather broad definition. Since globalisation is such a highly controversial subject, it is difficult to capture and to measure it. However, the suggested definition allows the identification of several distinctive indicators of the globalisation process:

$\square$ Globalisation extends social, political and economic activities across political frontiers.

$\square$ It intensifies international interdependence as flows of trade, investment, finance, migration and culture increase.

$\square$ It speeds up the world, since new systems of transport and communication mean that people, goods and capital travel much faster and the diffusion of societies and cultures by information and new ideas is more rapid and more difficult to control.

$\square$ Local developments in far-away places can have enormous global consequences.4 Thus, the phenomenon of globalisation involves an increase in transnational activities and interactions in several domains, which can be divided into economic, political, environmental, 
technological, military and cultural spheres.5 Consequently it is possible to argue that there are several types of globalisation which are related to transnational activities in the aforementioned areas.

It is important to note that globalisation is qualitatively different from interdependence. While enhanced interdependencies are undoubtedly part of the globalisation process, globalisation goes much further than interdependence. Interdependence focuses on the increase of linkages between different sovereign entities. Globalisation, however, generates the penetration of previously sovereign space. Therefore it includes not only the movement of goods and capital but also the circulation and interpenetration of cultures, societies, peoples and ideas. 6 These dynamics are causing many structural changes, including the rethinking of the role of national governments.7 Increasing international interdependence and the penetration of sovereign space by outside forces challenge traditional modes of governance.

Since the establishment of the Westphalian system the nation-state has provided the major framework of political organisation for the exercise of national governance. One of its main features is the link between sovereignty and territoriality.

... sovereign states rooted in territorial notions of social space have been the prime unit for facilitating, impeding and mediating interaction between the social groups, organisations, and citizens and other categories of collective and individual social units contained within their borders.8

Yet globalisation increasingly puts the effectiveness of territorial governance based on exclusive national sovereignty in question. Hence, a crucial precondition for successful governance at state level has been removed. National governments are increasingly unable to control multinational companies, ecological problems, international crime and terrorism or currency speculations efficiently, since these activities lack a territorial foundation. Globalisation is not an entirely new phenomenon. International transactions are as old 4 D.Held, A. McGrew,D.Goldblatt and J. Perraton, 'Managing the Challenge of Globalization and Institutionalizing Cooperation through Global Governance', in C. W. Kegley, Jr and E. R. Wittkopf (eds), TheGlobal Agenda-Issues and Perspectives (New York: McGraw-Hill, 2001), p. 135.

5 Held, 'Democracy and Globalization', p. 2.

6 J.-M. Guehenno, 'The Impact of Globalisation on Strategy', Survival, 40,4 (1999).

7 See R. G. Lipsey, 'Globalisation and National Government Policies: An Economist’s View', in J. H. Dunning (ed.), Governments, Globalisation and International Business (New York: Oxford University Press, 1997), pp. 73. 8 C.W. Hughes, 'Globalisation and Security in the Asia-Pacific: An Initial Investigation', University of Warwick, Centre for the Study of Globalisation and Regionalisation, Working Paper No. 61/00 (2000), p. 5.

124 Uwe Wunderlich

as the nation-state concept itself and nation-states have never been detached from their external environment.9 But due to restricted technological capabilities these kinds of transactions were of a rather limited nature compared with today and could be more easily controlled by national administrations.10 It is not the very existence of international activities but their extensiveness, their intensity, their velocity and the corresponding effects on society which create problems for the nation-state.

Of particular interest for the interpretation of the events across the Taiwan Strait in the post-Cold-War world are the security implications of the globalisation process. In this context it is important to mention the narrowing of the gap between exclusively domestic and exclusively foreign policies. The forces and characteristics of the globalisation process make such a distinction increasingly difficult. National governments are forced to contend with a freer flow of economic, social, political and cultural dynamics which move with declining reference to the previous limitations and channels imposed by national borders.11 The security implications of globalisation are threefold. First, as already indicated, national and international affairs become increasingly mixed and so are matters of internal and external security. Second, globalisation leads to a diversification of security threats and the creation of new security actors. And, third, globalisation results in a enhanced pronouncement of identity issues.12

Among the far-reaching effects of transnational political, economic and social activities, enhanced interdependence and the development of new and faster means of communication and transportation are the creation of new actors and new potential threats to the external and internal security of a nation-state. The dilemma arising out of globalisation for national 
governance was demonstrated by the devastating attacks on the World Trade Centre in New York on 11 September 2001. This traumatic event and the resulting crisis underlined the incapacity of even a state as powerful and technologically advanced as the United States to tackle independently a collective problem such as international terrorism. The enormous military power of the United States seems to be of limited use against an invisible and fragmented enemy with no territory of its own, thus defying conventional warfare. Retaliation and, therefore, sufficient deterrence are almost impossible without a target. The economic aftershock has been felt around the world. The struggle of the aviation industry in the aftermath of the attack is just one example and points to the indicators of globalisation as defined above: the effects of certain significant events will be felt in almost every region of the planet.

Economic globalisation has security consequences. Commerce and financial operations easily penetrate state borders. According to neoliberal arguments the spread of market forces is a precondition for economic development and growth. On the international level globalisation has the potential to facilitate a more peaceful environment due to the increasing interconnectedness of different national economies. However, economic factors can also have disintegrative effects and threaten the internal stability of a state and a society. On the national level, the opening of a society to the forces of international economics affects the welfare of different groups within the state. The downside of that is that the gains of economic development are seldom spread evenly. While some social and economic actors are benefiting, others will lose out. This kind of economic exclusion and disparity can result in social unrest and internal instability which affects the foreign policy behaviour of the state. Accordingly, domestic instability can translate into international 9 And so are the problems for the nation-state caused by powerful transnational actors such as, for instance, the East India Company.

10 In addition, the spread of globalisation was effectively limited by the Cold War dichotomy.

11 See Hughes, 'Globalisation and Security in the Asia-Pacific', p. 5.

12 See V. D. Cha, 'Globalization and the Study of International Security', Journal of Peace Research, 37,3 (2000).

Globalisation and Security in the Taiwan Straits 125

tensions. Possible reasons for that could be spillover effects such as migration and ethnic violence or simple diversion tactics employed by national regimes seeking legitimacy in nationalism and military adventures abroad. International competition caused by the globalisation process can also become a security problem. Some states will simply do better than others. The outcome of unmanaged competition can result in corruption and organised crime at the national level and the possibility of protectionism, arms races and the threat of military violence at the international level.

Environmental problems deserve also to be mentioned in this context. Environmental degradation such as global warming, ozone depletion, acid rain, pollution and so on have to be taken into account as possible security risks, since they are able to threaten the health of individuals and populations. The haze in Southeast Asia is a good example of that. The forest fires in Indonesia of 1997 had a devastating impact on the neighbouring countries. According to the Malaysian government, approximately 15,000 people had to be admitted to hospitals and clinics due to respiratory illness in 1997 alone. In December of the same year, the state of Sarawak was forced to declare a state of emergency, closing schools, businesses and government services for ten days. In addition, the haze brought significant losses to the tourism industries in Malaysia and Singapore.13

The developments in the information technology sector have dramatically enhanced the speed and size of international data flows. Via the internet and the mass media ideas, news, facts and propaganda travel faster and penetrate societies far more easily than ever before. These increased information and data flows are much more difficult for national authorities to control, if only because of the overload of incoming material or the technical problems of effective control and monitoring. Like the other indicators, this feature of globalisation can have disintegrative effects on the national and consequently the international level. Crime syndicates, terrorist networks, ethnic militias, paramilitary guerrillas and religious groups employing these new means of communication and transport are presenting new dimensions of security threat. Another possibility is the triggering of a reorientation of the loyalties of different subnational actors and the subsequent erosion of the collective identity 
of a society, resulting in the internal fragmentation of a state.

\section{The Globalisation Process and Its Security Implications for Cross-Strait Relations}

Now we have established the connection between the globalisation process, national governance and international security, the second part of the paper will analyse the implications of globalisation for the relations between the PRC and the ROC. The Taiwan Strait provides an interesting case study of the linkages between globalisation issues and inter-state relations. In this context it needs to be pointed out that while the tensions between the mainland and Taiwan date back to the late 1940s it can be argued that for most of the intervening time the conflict was constrained by superpower rivalry and, to a certain extent, even ritualised. It appears, however, that the dispute has been intensified and gained magnitude since the late 1980s. It is also roughly within that period that the forces of globalisation have become increasingly significant in international relations.

Assuming a strong linkage between these developments, the next two sections analyse the implications of globalisation for the domestic situations in China and Taiwan. The remainder of the article will then demonstrate the potential of domestic developments affected by forces associated with the globalisation process to influence the security relations across the Taiwan Strait.

13 R. Sukma, 'Security and Interdependence in Southeast Asia: View from Jakarta', Strategi, 7 (August 1999), p. 48. 126 Uwe Wunderlich

\section{China-Domestic Fragility}

By the 1970s the Chinese leadership had arrived at the conclusion that Maoist economic policies had failed utterly and had led to some of the worst crises in modern Chinese history, such as the catastrophic aftermath of the so-called 'Great Leap Forward'. The death of Mao Tse-tung in 1976 opened the way for economic reorganisation and the Chinese government began to enact a reform programme by opening the country to the international economy and therefore to the forces of economic globalisation.14 The domestic reforms were implemented gradually or as experiments - as the Chinese say, by 'feeling the stones across the river'.15 At first glance, the benefits have been breathtaking. In 2000, the PRC was the seventh biggest export nation and the eighth largest importer in the world. Exports and imports together were worth more than a staggering US\$470 billion.16 From 1979 to 1999, China’s GDP grew at an average rate of 9.7 per cent, making it one of the fastest-growing countries.17 Furthermore, infant mortality and life expectancy are nowadays comparable to those of many high income countries.18 A variety of domestic and foreign factors have been associated with that development. Among them are large-scale investment inflows, high factor productivity, relatively low wages and a rapid growth of exports.19 Altogether, it is possible to argue that the leadership in Beijing has succeeded in making China stand up and acquire sufficient weight to be taken seriously.20 Utilising the dynamics of the globalisation process has been a decisive factor in that achievement.

But one year after the accession of the country to the World Trade Organisation (WTO) the PRC is still facing a number of fundamental problems. The opening of China to market forces caused immense economic and social changes, producing factors at both national and international level which are threatening the internal stability of the country as well as affecting the relations of the PRC with other states. Many of China's current problems have been created by a system that has become an incredible engine for growth. One problem is internal political and economic disintegration. This process can be easily observed by contrasting the rapidly developing coastal areas in southern China with the poor and underdeveloped provinces of the hinterland. Of course, up to a certain extent even the latter have benefited from modernisation and globalisation but not to the same degree as, for instance, Hong Kong, Shanghai, Shenzhen or Guangzhou. These growing inequalities have resulted in an ongoing fragmentation of the country. Provinces and cities are competing with each other for foreign direct investment as well as in the international markets. The internal market of the PRC has become increasingly fragmented with intra-provincial trade declining and external trade increasing. The competition for scarce raw materials and quarrels over land, water and other resources have become evident in internal border conflicts.21 The gap between the prosperous east and the underdeveloped west of China is 
widening.

The economic modernisation of the country seems to have supported political fragmentation too. Market-based economic growth required the decentralisation of decision-making power away from the central state level to provincial government officials, local party 14 Mao died in the early hours of 9 September 1976. H. E. Salisbury, The New Emperors-Mao and Deng: A Dual Biography (London: HarperCollins, 1992).

15 See for instance R. Cheetman, 'Why We Need China to Succeed', Asian Wall Street Journal (9 August 1995).

16 D. Brown, 'China Joins the Club', The Guardian (11 December 2001).

17 In the early 1990s, double digit numbers of GDP growth were recorded.

18 See Cheetman, 'Why We Need China to Succeed'.

19 See, for instance, C. Findlay, 'China and the Regional Economy', in S. Harris and G. Klintworth (eds), China as a Great Power-Myths, Realities and Challenges in the Asia-Pacific Region (Melbourne: Longman, 1995), p. 286.

20 J. Gittings, ‘Fragile China’, The Guardian (7 March 2002).

21 W. Wo-Lap Lam, The Era of Jiang Zemin (Singapore: Prentice Hall, 1999), p. 254

Globalisation and Security in the Taiwan Straits 127

cadres and private enterprises. As a result, increasingly independent local power centres are forming with local officials ruling over their domains like the warlords of the 1920s. This seems to be tolerated by the central government on the condition that social and political stability is maintained and economic growth generated. Richard L. Grant mentions in this context that

the use of special economic zones as a primary vehicle for marketization creates difficulties in the exercise of central control over the Chinese economy. Although China may not yet have two capitals, as some believe, with political power centered in Beijing and economic power in Hong Kong or Guangdong, the ability of the center to influence economic decision making in the provinces has eroded.22

Unequal development is not only leading to an increasing fragmentation of the PRC. Internal problems are also caused by economic dislocation. Examples are the massive migration movements from the poor rural areas to the booming coastal cities. Over 100 million people, mostly peasants, have not benefited from the modernisation process in the last few years.23 Open unemployment caused by the reduction of state-owned enterprises, the diminishing of job security, and the uncontrolled migration of people into urban areas is emerging and growing rapidly. In spring 2002, Beijing's Labour Ministry sent a chilling message to millions of migrant workers who had returned home for holidays - that there would be no point in hurrying back into the cities, since vacancies were scarce. Gaps in income distribution are widening. In 2000 the average farmer's income rose by about 2 per cent while urban income increased by about 7 per cent in the same year.24 The differential access to higher education and services combined with the natural wage dispersion in modern market economies will create new inequalities between rich and poor and between rural and urban areas which will exacerbate social tensions.25

The problem, it appears, lies in the fact that Beijing adopted a two-tier approach to development-economic reform combined with political rigidity.26 However, opening to economic globalisation without a proper compensation mechanism for those who lose out in the process or are bypassed by it easily escalates into social unrest. The almost complete absence of efficient judicial instruments in the system to frame economic development will certainly cause further problems. Increasing unemployment and corruption and 27 geometrically rising price levels for those not enjoying the anticipated benefits of the new system were among the factors that gave rise to a movement of domestic dissatisfaction which eventually turned against the Beijing government and culminated in the 1989 Tiananmen incident.28

In March 2002, Zhu Rongji, prime minister of the PRC, denounced the rich-poor divide and serious corruption among government and party officials.29 The fact that corruption is recognised by Beijing's leadership as having serious implications and reaching into the highest levels of state was underlined by the execution after being found guilty of corruption charges of Cheng Kejie, a member of the National People’s Congress and deputy 22 R. L. Grant, 'China and Its Asian Neighbours: Looking toward the Twenty-First Century', Washington Quarterly, 17,1 (1994), pp. 65, 66

23 See J. R Faust and J. F. Kornberg, China in World Politics (Boulder:Lynne Rienner, 1995), p. 258.

24 Gittings, ‘Fragile China'.

25 For China's problems see also ‘China at Fifty', The Economist (2 October 1999), p. 23. 
26 Not to mention the uneven development of the country, which has created problems of its own.

27 Large parts of the state and the armed forces have themselves turned toward the profit motive. Indeed, corruption is turning out to be a very serious problem. Economist Hu Angang has estimated that during 1999-2001 the total costs of corruption amounted to 14 per cent of China's GDP per year. Gittings, 'Fragile China'.

28 On Tiananmen see M. Fathers and A. Higgins, Tiananmen-The Rape of Peking ( London: The Independent in association with Doubleday, 1989) and H. E. Salisbury, Tiananmen Diary-Thirteen Days in June (London: Unwin, 1989).

29 J. Gittings, 'China's Premier Hits out at Corruption', The Guardian (6 March 2002).

128 Uwe Wunderlich

of Li Peng, in September 2000.30 Corruption can, indeed, be described as one of China's major internal threats. In 2000, the authorities released details about a huge scandal—a US\$ 6 billion smuggling case involving more than 200 middle-ranking and senior local party and police officials as well as a deputy minister of public security. That was most likely not an isolated event. In Guangdong Province, a tax fraud case is under investigation which could well eclipse the smuggling case. Internal unrest is constantly caused by official wrongdoing: in August 2000, thousands of farmers in Jiangxi rioted against excessive and illegal taxes imposed by local officials.31

China's accession to the WTO has the potential to exacerbate an already tense situation. It has been estimated that entry to the WTO will deprive Chinese farmers of around 20 million jobs. Faced with enhanced foreign competition the already badly hit state industries will have no alternative but to continue to lay off employees. Factory closures, growing unemployment and the acceptance that other countries will achieve influence in the setting of China's economic policies will pose new challenges to Beijing.

Other indicators of the globalisation process are increasing economic interdependencies and the development of trade, financial and political linkages across state borders. This might subsequently result in the formation of new territorial entities oblivious to the constraints of national borders. China's economic power centres along the southern coastline have increasingly more in common with other major economies in Northeast Asia such as Japan, Taiwan and South Korea. A network of linkages of all sorts, especially of finance, trade and labour division, seems to be creating a zone of economic interdependence connecting these economic hotspots. In a relatively recent book on regionalism, Bjo"rn Hettne distinguishes between three different types of regions with reference to their position in the contemporary global structure. These regions can be categorised according to their relative political stability and their relative degree of sustained economic dynamics. Accordingly, 'Greater China', containing coastal China, Hong Kong and Taiwan, belongs to the so-called intermediate regions, while the interior of China belongs to the peripheral zone.32

China is facing a dilemma. Globalisation in general and economic globalisation in particular are driven by transnational activities and, thus, are largely outside the control of national authorities. Closing the country to the forces of globalisation or imposing tighter regulations could limit the potential economic gains and restrict the long-term prospects for prosperity. At the same time, however, analysis has shown that openness to the international political economy could undermine the domestic stability and security of the PRC.33

\section{Taiwan-Political Development}

The origins of the conflict between the ROC and the PRC date back to the Chinese Civil War. In the late 1940s, a flood of mainland refugees crossed the Taiwan Strait.34 Chiang Kai-shek's Kuomintang were finally forced to retreat to Taiwan, where they were able to consolidate their position though losing the mainland at the same time. On 1 October 1949, Mao Tse-tung proclaimed the PRC and effectively created two Chinas: the PRC with its 30 International Institute for Strategic Studies, 'Strategic Survey 2000/2001' (London: Oxford University Press, 2001), p. 180.

31 International Institute for Strategic Studies, 'Strategic Survey 2000/2001', pp. 180, 181.

32 B. Hettne, 'Regionalism, Security and Development: A Comparative Perspective', in B. Hettne, A. Inotai and O. Sunkel (eds), Comparing Regionalism-Implications for Global Development (Basingstoke: Macmillan, 2002),

p. 3.

33 S. Harris, 'China and the Pursuit of State Interests in a Globalising World', Pacifica Review, 13,1 (2001), p. 26.

34 In 1949 alone, approximately 1.6 million civilians and military personnel crossed the Taiwan Strait.

Globalisation and Security in the Taiwan Straits 129

administration in Beijing and the ROC with Taipei as its capital. Both governments actively advocated the eventual reunification of Taiwan with the mainland although there were 
obviously substantial differences about who should rule in Beijing.

While reunification was on the agenda of both governments during the Cold War, a possible invasion of the mainland from Taiwan became less and less likely. During the 1980s, forced by changes at the international level and internal pressure, the Taipei regime began an internal reform programme characterised by a transformation of the Kuomintang, slow steps towards democratisation and the emergence of Taiwan as a de facto independent state. Until the mid-1980s there was little contact between the PRC and the ROC. Trade relations were of an indirect nature and went through Hong Kong. An important breakthrough occurred in 1987 when President Chiang Ching-kuo lifted martial law, allowed Taiwanese citizens to travel to the mainland and legalised the formation of political parties.35 Political liberalisation reflected domestic changes in Taiwan. Being one of the so-called ‘newly industrialised countries' (NICs), the ROC underwent an impressive economic development. Over the years, the trade linkages with the mainland increased. According to figures released by Taiwan's Ministry of Economic Affairs, mainland trade grew constantly while other trade declined relatively from the late 1980s onwards.36 There was a demand from Taiwan's business community to create possibilities for expansion of the economic linkages with the PRC.

Taiwan's economic development facilitated the establishment of a well-educated middle class who demanded more civil liberties. Opposition candidates began to coordinate their activities. Within the ruling party, the Kuomintang, a generational change took place. The old leadership was replaced by younger, highly trained (often overseas-educated) bureaucratic technocrats. Civilians began to take over and Taiwan became governed by a professional bureaucracy rather than the military. Additionally, more and more native Taiwanese acquired leading positions within the party structure, government, army and the security services.

The democratisation and liberalisation of the ROC were caused by a mixture of domestic and international factors. The internal determinants have already been indicated. With regard to changes in the international environment of the 1980s and 1990s, the Taipei regime realised that it was just not enough any more simply to be an anti-communist government. Against the background of the Sino-US rapprochement, liberalisation and step-by-step democratisation became increasingly a self-interest of the ROC and the Kuomintang, since they provided an opportunity—-perhaps the only one-to gain domestic and international legitimacy. Crucial milestones in this process were the presidential elections of 1996 and 2000. The elections of 1996 signalled, in a way, the end of the political transition process into the direction of fully fledged democracy. That was reinforced in 2000 when Chen Shui-bian of the Democratic Progressive Party (DPP) became president of the ROC. The electoral outcome ended more than fifty years of Kuomintang rule. The smooth transfer of power can be regarded as passing successfully the ultimate test for democracy.

The penetration of Taiwanese society by international economic, political and cultural forces can be regarded as an important factor in the democratisation of the ROC. Domestic democratisation and party politics supported the emergence of something like a Taiwanese identity. The notion of identity has its roots in the social needs of individuals to categorise 35 J. B. Jacobs and L. Hong, 'China's Relationship with Taiwan', in Harris and Klintworth, China as a Great Power, p. 25.

36 Ministry of Economic Affairs-Board of Foreign Trade, http://www.moeaboft.gov.tw/english.htm. Accessed 25 March 2002.

130 Uwe Wunderlich

and classify themselves and the social group they belong to. Such a group identity fulfils two functions. It describes who belongs to the group while, at the same time, distinguishes the group from its external environment. In that way it becomes possible to identify insiders and outsiders and create a kind of 'we-group' feeling.37

Generally speaking, identities are never fixed but are always subject to constant transformation and readjustment. They are dependent on time and context. Furthermore, identities are not absolute. Therefore, individuals can belong to more than one group at the same time. People can thus assume multiple identities.38 Individuals can regard themselves as members of a family/clan, inhabitants of a certain street/village/town/region, employees 
of a certain company while being at the same time members and representatives of a nation, a cultural minority, followers of a religion and citizens of a state. Hence, the context is of crucial importance. However, frictions might arise if different groups impose conflicting demands on their members.39

The multiple identity framework is of particular interest with regard to the issue of a collective identity. For the construction of such an identity some form of binding element is needed. These links can take all sorts of shapes. Examples are a common culture, a common ethnic background, shared linguistic similarities, common experiences, a common heritage, shared norms and values. The process of political liberalisation and democratisation seems to have accelerated the construction of a Taiwanese national identity. As already mentioned, the economic development of Taiwan facilitated the formation of a well-educated urban middle class that increasingly asserted itself politically. This domestic pressure was an important element in the liberalisation of the ruling Kuomintang. Before the 1990s, Taiwanese identity was actively suppressed by the Kuomintang, which, originally, was a mainland party. However, democratisation and liberalisation caused a 'nativisation' of the party. The rise of Lee Teng-hui, a native Taiwanese, through the party ranks to eventually become Taiwan's first elected president is the best example of that. It appears that the cornerstones of this formative identity are the values of economic progress, democracy and freedom.40 In this context it deserves to be mentioned that the emergence of an independent Taiwanese identity is probably not such a recent phenomenon as suggested above. It could be argued that attempts to form an independent national identity have a long tradition and it is the discontinuities of history, i.e. the successive colonialisation and occupation by foreign regimes and by the Chinese mainland, that impeded the coming to maturity of a stable national identity. Following this logic, the current process of identity formation is only the latest wave-although with the strongest potential to become consolidated.

Taiwan's emerging identity implies a departure from the 'one China principle'. The current vice president of the ROC, Annette Lu Hsiu-lien, told inquiring journalists that Taiwan's history is different from that of the mainland because of the long-lasting Japanese occupation. Taiwan and China are close neighbours but also distant relations. And, finally, Taiwan is already as good as independent and sovereign. Lu Hsiu-lien also makes no secret of her support for Taiwan's membership of the United Nations.41

Another indicator of the increasing self-consciousness of the de facto state is the

37 See G. Elwert, 'Nationalismus und Identita"t. U” ber die Bildung von Wir-Gruppen', Ko"Iner Zeitschrift fu"r Soziologie and Sozialpsychologie, 41 (1989), pp. 440-464.

38 For an interesting analysis of the evolution of multiple identities in France and Germany see J. Schild, 'National v. European Identities? French and Germans in the European Multi-level System', Journal of Common Market Studies, 39,2 (2001), pp. 331-351.

39 See W. Loth, 'Identity and Statehood in the Process of European Integration', Journal of European Integration History, 6,1 (2000), p. 20.

40 See J. Kuo, ‘Building a Taiwanese National Identity’, Taipei Times (21 June 2001).

41 'Taiwan Takes Another Broadside from the Mainland', The Economist, 355,8166 (2000) p. 75.

Globalisation and Security in the Taiwan Straits 131

outcome of the 2000 presidential election. Despite Beijing's stern warnings, menacing rhetoric and tactics of intimidation, electoral victory went to Chen Shui-bian, whose DPP had long supported the idea of Taiwanese independence. Chen Shui-bian mentioned in his inaugural speech 'special historical and geographical factors' as well as 'a wealth of diversified cultural elements'. He also emphasised 'Taiwan's local cultures' in contrast to 'the cultures of Chinese-speaking communities'. His emphasis on Taiwan seems to signify a new stage in the identity-building process of the island.42 There is nothing intrinsically wrong with that. Nor do Taiwanese and Chinese identities have to be mutually exclusive, as the multiple identity framework suggests. However, while previously the Taipei government opposed the communist regime in Beijing but did not detach itself from China's

future, there is now an increasing trend of opposing China itself and not just the Chinese Communist Party:

Professor Szu-yin Ho... says that in the last several years there has been 'a dramatic decline in the number of people who identify themselves as Chinese only, and an increase in those who identify themselves as both Chinese and Taiwanese, or only as Taiwanese.' People on Taiwan, 
he says, are 'similar culturally but different in thinking' from those on the mainland.43 The harassing attitude of the PRC towards Taiwan only seems to reinforce the emergence of a separate national identity on the island. As the previous section has argued, the dynamics of globalisation have the intrinsic potential to cause further deterioration of the already rather tense domestic situation on the mainland. It is possible to argue that this might motivate Beijing to increase its threats towards Taipei. That in turn would only strengthen the emergence of a Taiwanese identity independent from the mainland, which would have serious long-term political, economic and social consequences for cross-strait relations.

\section{Security Implications of the Globalisation Process for Cross-Strait Relations}

So far the discussion has clarified two things. First, China's internal future remains uncertain. Beijing's major problems are of a domestic nature, including political, economic and social fragility and uneven economic development. It has been argued that forces that can be attributed to the globalisation process are at least partially responsible for these issues and certainly contain the potential to destabilise the situation even further. Second, at the same time, democratisation and political and social liberalisation, enhanced by the globalisation process, are supporting and strengthening the slow emergence of a Taiwanese identity that, increasingly, seems to point in the direction of a formally independent Taiwan. For constructivist scholars such as Alexander Wendt identity issues and the formation of identity are central concepts for the understanding and interpreting of international relations. 44 These identities are subject to change through interaction and influence domestic and foreign security matters. According to Amitav Acharya constructivist theory interprets the conflict between the mainland and Taiwan as a clash of two emerging identities.45 On the mainland, this identity is increasingly nationalistic and sovereignty bound due to the 42 Kuo, 'Building a Taiwanese National Identity'.

43 F. Ching, 'China's Task: Woo Taiwan', Far Eastern Economic Review (4 November 1999).

44 See A. Wendt, 'Constructing International Politics', International Security, 20,1 (1995) and A. Wendt, 'Identity and Structural Change in International Politics', in Y. Lapid and F. Kratochwil (eds), The Return of Culture and Identity in IR Theory (London: Lynne Rienner, 1996). See also A. Wendt, 'Collective Identity Formation and the International State', American Political Science Review, 88,2, (1994).

45 A. Acharya, 'International Relations Theory and Cross-Strait Relations', Taiwan Security Research (1999), http://www.taiwansecurity.org. Accessed 9 August 2002.

132 Uwe Wunderlich

aforementioned problems while Taiwan is developing an enhanced understanding of itself as a distinct, democratic and independent international entity—in political, cultural and economic terms. Therefore, the two sides have a different outlook on and a different interpretation of cross-strait relations. The connection between globalisation and international security is to be found in the penetration of sovereign space, its effects on the domestic situation of a state (including the self-understanding of this state) and its translation into foreign policy behaviour. Consequently, the two developments mentioned above will determine the future of security in the Taiwan Strait. On the international level the impact of globalisation on PRC-POC relations can be demonstrated across the spectrum of international relations theory by utilising the analytical instruments offered by the neorealist and the neoliberalist schools of thought.

\section{The Impact of Globalisation on the Taiwan Strait: A Neoliberal Perspective}

Neoliberalism tends to provide an optimistic and forward-looking picture of the development of international security and globalisation. Proponents of this model focus primarily on the pacifying effects of globalisation: growing international trade and increasing interconnectedness between different economies and societies substantially increase the costs of armed conflict. In addition, it is often argued that these linkages support a steady movement towards democracy and the establishment of multilateral institutions. Adapted to cross-strait security the liberal/neoliberal paradigm holds to the proposition that globalisation carries the potential to stabilise the domestic situation of the PRC. First, continuing economic growth provides the government with a certain degree of legitimacy and could lead to eventual political liberalisation. A prime example of that is Taiwan itself. 
In fact, China these days looks a bit like the ROC in the 1970s: a one-party authoritarian regime with a market economy that places high priority on domestic order and stability. One writer has offered a good expression to characterise the PRC: 'Market-Leninism'.46 The prospering of the private economy is already creating a new power base outside the ruling Chinese Communist Party (CCP). It fosters the formation of a new and wealthy urban middle class that is increasingly insisting on political participation. New means of communication and transport make effective censorship almost impossible. A Chinese-style civil society is slowly emerging and growing. Over the last couple of years a huge number of non-official professional, academic, business, research and other organisations have been created. Consumer associations are forming in many medium-sized and large cities, enthusiastically asserting themselves. Private entrepreneurs have actively started to lobby for political influence.47 The rise in the general education levels as well as pressure from abroad might, eventually, work in favour of political liberalisation. However, continuing economic growth alone will not be sufficient. It has to be accompanied by the establishment of an efficient judicial system and working compensatory mechanisms and social safety networks.

A stable and politically reformed China will then have a different foreign policy outlook. This argument is based on the assumption that the opportunity costs of interdependence are low while the costs of an aggressive foreign policy are prohibitively high. The costs of conflict result from the disruption to markets and investment flows. Economic relations and interdependencies with other states and the world economy make China more vulnerable to such dislocations while at the same time fostering habits of communication 46 N. D. Kristof and S. Wudunn, China Wakes-The Struggle for the Soul of a Rising Power (London: Nicholas Brealy, 1994). 47 Wo-Lap Lam, The Era of Jiang Zemin, p. 304.

Globalisation and Security in the Taiwan Straits 133

and compromise.48 The incentives for conflict are furthermore lowered, since the open international economy allows relatively free access to other markets. Resources and finance can be obtained at less cost than by securing spheres of influence with the help of military operations. Furthermore, globalisation empowers a variety of different groups within state and society which have a more pragmatic view of foreign policy.

The prospect of an economically developed and politically liberalised mainland provides the opportunity for a clear improvement of cross-strait relations. Taipei would find it far easier to communicate with a democratically elected government in Beijing. Increasing economic exchange across the Taiwan Strait will benefit both sides and reduce the risk of conflict. Most crucially, the identity of the ROC would not have to be in opposition to mainland China - assuming that Taiwan's emerging identity is based on economic progress and on the values of 'democracy' and 'freedom'. Taiwan's identity-building process does not have to be reversed. The multiple identity framework makes it possible to be Chinese and Taiwanese at the same time. Eventually, reunification becomes possible. Being part of a democratic and developed PRC certainly would be in the interest of Taiwan's business community since access to the Chinese market would be easier and the transaction costs for Taiwan-China trade would be reduced. Furthermore, such a move would enhance Taipei's standing in the international community. Taiwanese companies would be enabled to trade on their own terms without being affected by the weak international position of the ROC. It makes sense to think about the reunification as a process in two stages: an economic and monetary union with a common market would provide the groundwork, which might, eventually, be followed by a full political union of the ROC and the PRC.

\section{The Impact of Globalisation on the Taiwan Strait: A Neorealist Perspective}

Realism offers a rather less optimistic picture. Realists and neorealists do not accept the validity of the optimistic liberal/neoliberal argument. This school is more concerned with the distribution of capabilities, balances-of-power and strategic equilibria. Accordingly, it focuses more on the destabilising effects of the globalisation process. The problems of China's fragile domestic system have already been mentioned. Globalisation makes the PRC more vulnerable to outside shocks such as the Asian financial crisis of the late 1990s. Although China escaped relatively unharmed the crisis demonstrated that social dissatisfaction 
triggered off by such an event can lead to internal upheaval and social unrest, subsequently leading to an open challenge to the ruling regime.49 Beijing's leadership is worried about such possibilities. That might explain the drastic crackdown and the policy of zero tolerance towards the Falun Gong movement. While neither the movement nor the protests following the crackdown represent a threat to the government, they signal the diminishing ability of the Beijing regime to command public obedience. It would be too much to characterise the Falun Gong sect as a civil protest movement, but it has evoked lingering sympathy not only among the general public but even within the CCP and the security services.50 A tense domestic and unstable domestic situation would find expression in China's foreign relations. Failing increasingly to legitimise its leadership through economic prosperity and losing domestic support, the Beijing government would be prone to claim

48 B. Buzan and G. Segal, 'Rethinking Asian Security', Survival, 36,2 (1994), p. 11.

49 The fall of Suharto in Indonesia offers the best example of that.

50 To the Communist Party's problem with domestic religious movements, especially with the Falun Gong, see G.

C. Chang, The Coming Collapse of China (London: Century, 2001), p. 17.

134 Uwe Wunderlich

legitimacy through nationalist claims and a more aggressive foreign policy. Jiang Zemin’s approach to governance seems to favour Maoist-style 'mass movements' that foster nationalist tendencies.51 There are many signs that Jiang's vision of China's future advocates nationalist values combined with a tight law-and-order regime. 52 Nationalism could be an effective instrument in holding China together. As a result, domestic dissatisfaction could be easily turned against external targets—such as the renegade province of Taiwan. At the same time, this kind of development on the mainland would reinforce the emerging identity of the ROC in contrast to China.53 Conflict and tensions and a general deterioration of security across the Taiwan Strait are almost pre-programmed under such a scenario.

But even if we assume China will not be affected by an international economic crisis and will be able to generate sufficient rates of economic growth, eventually being able to stabilise its domestic situation, the realist/neorealist school does not argue for a necessary improvement of security in the Taiwan Strait. Many Chinese equate economic growth with national power. Growth allows the PRC to build up its armed forces and to project itself as a regional power.54 China's analysts are very much influenced by traditional balance-ofpower thinking. 55 The country is not satisfied with the current status quo and China's economic growth will provide it with the necessary means for a more assertive foreign policy. The realist framework sees China's economic potential, its inherent strength, its view of itself and its eagerness to redeem a century of humiliations as important factors behind China's foreign policy behaviour.

China's military budget has risen significantly at a time when external threats are low.56 Official sources show a 17.1 per cent rise of the military budget in 2001, a figure much higher than the overall economic growth of the country.57 The modernisation programme of the People's Liberation Army (PLA) put particular emphasis on the acquisition of weapon technologies with the capability for long-range power projection.58 A growing economic base will increase the opportunities for Beijing to establish greater control over its external surroundings while at the same time the costs for doing so are decreasing.59 As a great power, China will be more inclined to force its will upon others. Beijing is already very reluctant to join binding multilateral security agreements.60 Based on the realist framework the incentives for limited expansionism would be irresistible. Beijing still believes that military operations are useful in international politics; it doubts the efficacy of multilateral cooperation and in fact prefers domination.

The analysis draws a picture of a China which challenges the current status quo in the region, with a serious deterioration of relations with Taiwan as one of the results. The 51 Wo-Lap Lam, The Era of Jiang Zemin, p. 3.

52 B. Gilley, 'Jiang’s Turn Tempts Fate', Far Eastern Economic Review (30 August 2001).

53 The outcome of the 2000 presidential election in the ROC is only one example of the counterproductivity of Beijing's policy of threats and intimidation towards Taiwan.

54 'China Opens up', The Economist (20 November 1999), p. 13

55 See J. T. Christensen, 'Chinese Realpolitik’, Foreign Affairs, 75,5 (1996), p. 37. 
56 J. Page, 'China Said Set to Announce More Military Spending', Reuters (4 March 2002), http://taiwansecurity.org/ Reu/2002/Reuters-030402.htm. Accessed 25 April 2002.

57 See Chang, The Coming Collapse of China, p. 38.

58 On China's military modernisation see D. Roy, 'The “China Threat Issue” ', Asian Survey, 36,8 (1996), p. 759 ,

N. D. Kristof, 'The Rise of China', Foreign Affairs, 72,5 (1993), p. 65; D. B. Denoon and W. Frieman, 'China's

Security Strategy-The View from Beijing, ASEAN and Washington', Asian Survey, 36,4 (1996), p. 424; and R.

Bernstein and R. B. Munro, 'The Coming Conflict with America', Foreign Affairs, 76,2 (1997), p. 24. See also

B. Gertz, 'China Assembles Missiles Near Coast Facing Taiwan', Washington Times (2 April 2002).

59 D. Roy, 'Hegemon on the Horizon? China’s Threat to East Asian Security’, International Security, 19,1 (1994),

p. 161.

60 G. Segal, ‘Tying China into the International System’, Survival, 37,2 (1995), p. 60 and M. B. Wallerstein, 'China and Proliferation-A Path Not Taken?', Survival, 38,3 (1996), p. 58.

Globalisation and Security in the Taiwan Straits 135

neoliberalist model focuses on political liberalisation, which, in a way, is supported by forces generally ascribed to the globalisation process. However, even a democratically elected government would have difficulties with giving up the sovereignty claims on Taiwan without running into trouble at home. Furthermore, China does not necessarily have to take the 'Taiwan road'. The 'Singapore model' is also possible: a brilliantly managed market economy without the ballast of Western political standards which satisfies Beijing's desire for order and stability. It could also develop into a second Indonesia, which, until recently (under Suharto), enjoyed industrial growth combined with one-party rule. The Suharto regime, like the CCP, preferred using force to suppress dissidents or to massacre independence movements when the authority of its leadership was challenged. There is already some evidence for the transformation of the CCP into the right-wing authoritarianism of a Suharto.61

A strong China is likely to become more impatient with the ROC. It will renew its threats to use force to bring reunification about on Beijing's terms. The danger with applying the realist model too literally lies in the fact that it can become something like a self-fulfilling prophecy. Taipei would realise that its long-term strategy to foster development and democratisation in China is not paying off. A fully developed China would be much more difficult to deal with, bearing in mind that Beijing never has rejected military force as a means of resolving the issue. Taiwan would run out of time. Hence it would probably increase its efforts to achieve formal independence, trying to become a member of the United Nations and other governmental and non-governmental organisations. The ROC would also be well aware of Sino-US relations. Under such conditions, it would be in Taiwan's best interest to declare de jure independence before China is fully developed. At first glance that move seems to be irrational. However, if we look a little bit more closely it turns out to be the only rational choice if the ROC intends to survive as a state. First, while China is midway in its development process, Taipei still has the capabilities to hold off sufficiently any attempted invasion from the mainland. The ROC simply cannot afford to wait until China becomes too strong to be contained-or until the United States is too weak to contain China or no longer sees its interest in protecting Taiwan. Although a declaration of Taiwan's independence in the near future would be rather inconvenient for Washington, the United States would be trapped by its own rhetoric.62 That might have been part of the rationale that motivated the former president of the ROC, Lee Teng-hui, to mention in an interview that the relations between the mainland and Taiwan should be conducted on a 'special state-to-state' basis, although it inevitably brought cross-strait relations to a dangerous point.63

If Taiwan declared formal independence, Beijing would have no choice but to act. Its response could be anything from naval blockades to ballistic missile attacks. Even invasion attempts are not impossible, although rather unlikely given the current development status of the PLA. Whatever measures the PRC might employ in such a scenario, the security situation of the Taiwan Strait and the whole of the Asia Pacific would seriously deteriorate. A recent white paper states,

61 Gilley, 'Jiang's Turn Tempts Fate'.

62 President Bush declared at Beijing's Qinghua University that he was prepared to defend Taiwan if it were to be attacked by the mainland. That marks a change from the attitude of former US administrations towards the issue. No previous US president has mentioned the commitments of the Taiwan Relations Act while visiting China. (J. Gittings, 'Bush Tells China that He Will Defend Taiwan', The Guardian [23 February 2002].) However, it has to be remarked that it is official US policy not to support Taiwanese independence. That was underlined at the 
2002 Jiang - Bush summit, where President Bush clearly expressed US opposition to Taiwan independence and his adherence to the one-China policy. See C. Cockel, 'No Surprises for Taiwan from Bush-Jiang Summit', China Post (27 October 2002).

63 ‘Taiwan’s High-Stakes Game’, The Economist (21 August 1999).

136 Uwe Wunderlich

if a grave turn of events occurs leading to the separation of Taiwan from China in any name... then the Chinese government will have no choice but to adopt all drastic measures possible, including the use of force, to safeguard China's sovereignty and territorial integrity, and achieve the great cause of reunification.64 To summarise, the realist outlook on SinoTaiwanese relations provides a rather negative perspective on the effects of globalisation on cross-strait security, with the possibilities of increasing competition between the two states, mounting threats, enhanced intimidation and increasing political pressure on Taiwan from the mainland.

\section{Constructivism and Globalisation in the Taiwan Straits}

Both the neoliberal and the neorealist paradigms have been considered because they represent alternative and very different lenses of looking at and explaining international events and processes. They represent opposite ends of the theoretical spectrum of international relations. They have their own intrinsic weaknesses and draw two very different conclusions regarding the globalisation process and its implications across the Taiwan Straits. In both instances, however, the impact of globalisation plays a crucial role in the development of the security relations between the two countries countries.

The third major paradigm of contemporary international relations theory is social constructivism. The characteristics of constructivism and its relevance for the interpretation of PRC-ROC relations have already been mentioned above. Whereas neorealism and neoliberalism are based on rational choice theory and take the identities and interests of actors as given, constructivist theories start from the presumption that international structures are social constructs. Identities and interests of international actors are then formed through interactions and processes (such as the globalisation process) and not prior to them. In applying a constructivist way of thinking to the dynamics of the globalisation process and international security in the Taiwan Strait, emphasis will be placed on the impact of globalisation on identity formation and reshaping in the PRC and the ROC. This has already been elaborated in sufficient detail. On the mainland globalisation seems to pronounce an intensely nationalist, centralised and sovereignty-bound identity that stresses reunification with Taiwan as a crucial part of its self-perception. On Taiwan, on other hand, globalisation has supported the development of a democratic state that is becoming increasingly aware of its own distinct national identity. It is imperative to understand that constructivism can be pessimistic as well as optimistic regarding the effects of globalisation on cross-strait security. While China is opening its doors to the forces of the globalisation process and is becoming a member of the international political economy, Taiwan represents an important economic asset to Beijing. Adherence to international norms and socialisation processes might change Beijing's outlook on cross-strait relations. The same applies for Taiwan. However, an economic shock could easily exacerbate an already rather tense situation. It is the stress on factors such as identities which makes constructivism an interesting paradigm for the study of globalisation and security.

\section{Conclusion}

The paper has outlined the connections between the globalisation process and its implications for international security. Globalisation leads to an increasing penetration of sovereign space by external forces and therefore challenges traditional modes of governance. As a result, domestic and international affairs are becoming increasingly intertwined and so are 64 Information Office of the State Council, 'China's National Defense in 2000', White Paper, http://english. peopledaily.com.cn/features/Ndpaper/nd.html. Accessed 9 April 2002.

Globalisation and Security in the Taiwan Straits 137

domestic and foreign policy measures. In addition, globalisation supports the diversification of security threats and the creation of new security actors and enhances the pronouncement of identity. Transnational political, social and economic activities have the intrinsic potential to threaten the internal stability of a nation-state, which in turn will affect the foreign policy approach of its national government.

In applying this framework to the situation in the Taiwan Strait the analysis has 
concluded that two features are among the most crucial determinants for the future relations of the PRC and the ROC. These are the domestic stability of China and the development of a Taiwanese political identity. Globalisation has a great impact on the internal circumstances of the PRC as well as on the identity construction process in Taiwan and, therefore, on the security of the Taiwan Strait. Study of the Sino-Taiwanese conflict has demonstrated that globalisation is a determining factor in international security across the theoretical divide of international relations. The scenarios described above indicate that globalisation forces carry the potential for either improvement and eventual reunification, or a serious deterioration and even armed struggle. However, so far no clear direction is identifiable. Regardless of which school of thought is being applied, globalisation has a decisive impact on Sino-Taiwanese relations and on the security of the Taiwan Strait. The theoretical frameworks were applied for demonstrative purposes only. The reality of international relations is far more complicated than any of these paradigms can comprehend. Although there is much evidence supporting the realist/neorealist argument, China's restrained response to the outcome of the 2000 presidential elections in the ROC suggests that the more pragmatic forces in Beijing remain firmly in control of the PRC's external relations despite increasingly public expressions of virulent nationalism.65 Nevertheless, the Beijing administration cannot afford to go soft on the Taiwan issue. This could explain the repeated threats towards the island. It is, however, important not to over-emphasise the mainland rhetoric. Researchers such as Gary Klintworth argue in a convincing manner that China has no real intentions of going to war with Taiwan.66 In terms of domestic and international security much depends on other factors such as the forthcoming leadership change of the CCP. It is in connection with these other factors that the forces of globalisation will exert their full influence upon cross-strait relations.

65 International Institute for Strategic Studies, 'Strategic Survey 2000/2001', p. 172.

66 G. Klintworth, 'China, Taiwan and the United States', Pacifica Review, 13,1 (2001), p. 55. 